\title{
Seasonal Lawn Mower Operator Crushed and Dies After Lawn Mower Rolls Over on a 30 Degree Slope
}

\section{CASE SUMMARY}

On July 24, 2015, a 22-year-old lawn mower operator was killed when he was involved in a lawn mower rollover incident. The victim was mowing horizontally on a hill with a 30 degree slope when his mower slid down the hill and rolled onto him. Landscaper crewmembers also working in the area discovered the victim pinned beneath the mower at the bottom of the slope and immediately removed the lawn mower from on top of the victim, discovering he was deceased. The medical examiner identified the cause of death as asphyxia caused by chest compression.

\section{CONTRIBUTING FACTORS}

Key contributing factors identified include:

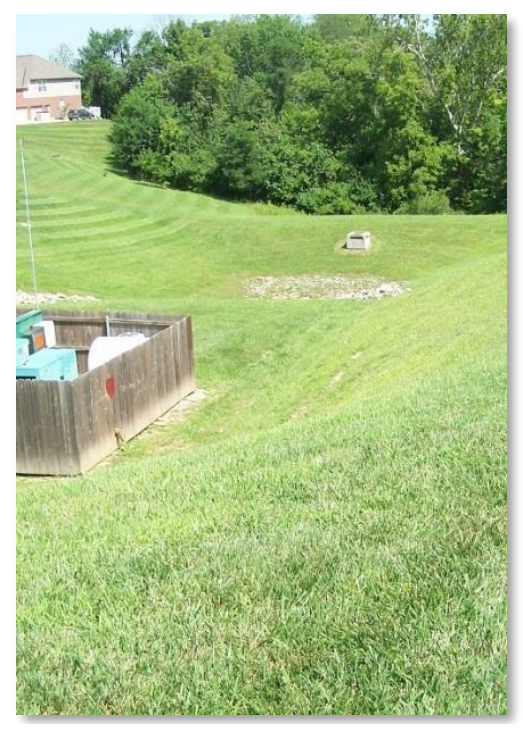

Figure 1. Area where mower overturned at jobsite.

- Operating a riding mower on a slope that exceeds manufacturer's specifications.

- The SCAG turf tiger riding mower was not equipped with a rollover protection structure.

- The employee was working alone.

\section{RECOMMENDATIONS FOR PREVENTION}

- Never operate a lawn mower on a slope that exceeds the angle limits specified by the lawn mower manufacturer; use lawn maintenance equipment designated for steep slopes.

- To prevent rollover injuries, riding lawn mowers should be equipped with roll-over protective structures (ROPS) and seat belts.

- Employees should receive safety training on slope mowing with riding lawn mowers that includes slope calculation, manufacturer specifications, and terrain assessment.

- Employers should consider implementing a buddy system when working in hazardous areas such as steep slopes. 


\section{EMPLOYER}

The employer is a large, privately owned, full service landscape company that has been in business since 1980 and currently has four locations. The company provides several services, including grounds management, snow and ice management, landscape design and installation, and irrigation system installation. At the time of the incident, the company employed 115 workers, some seasonally.

\section{SAFETY AND TRAINING PROGRAMS}

The employer provided formal written safety programs in both English and Spanish. The victim's name appeared on weekly training sign-in sheets dating back to 2014. The 2015 sheets did not list any of the company's Hispanic employees.

Documentation was provided indicating the victim had received the following training:

\begin{tabular}{|l|l|}
\hline Date & Training task \\
\hline $4 / 30 / 14$ & Bed care training, as well as weed trimmer training \\
\hline $5 / 13 / 14$ & Mower safety and proper lifting \\
\hline $5 / 20 / 14$ & Bed care \\
\hline $6 / 6 / 14$ & Bed care \\
\hline $6 / 9 / 14$ & Weed spraying \\
\hline $6 / 24 / 14$ & Backup training and mower safety \\
\hline $7 / 1 / 14$ & Weed trimmer training \\
\hline $7 / 22 / 14$ & No idling training \\
\hline $8 / 13 / 14$ & Mower safety, trimming safety, bed care, weed spraying \\
\hline
\end{tabular}

\section{VICTIM}

According to the death certificate, the victim was 22 years old with an 8th grade or less education. He was born in Mexico and had been employed as a lawn maintenance worker with the company for 1 year and 4 months on a seasonal basis. 


\section{INCIDENT SCENE}
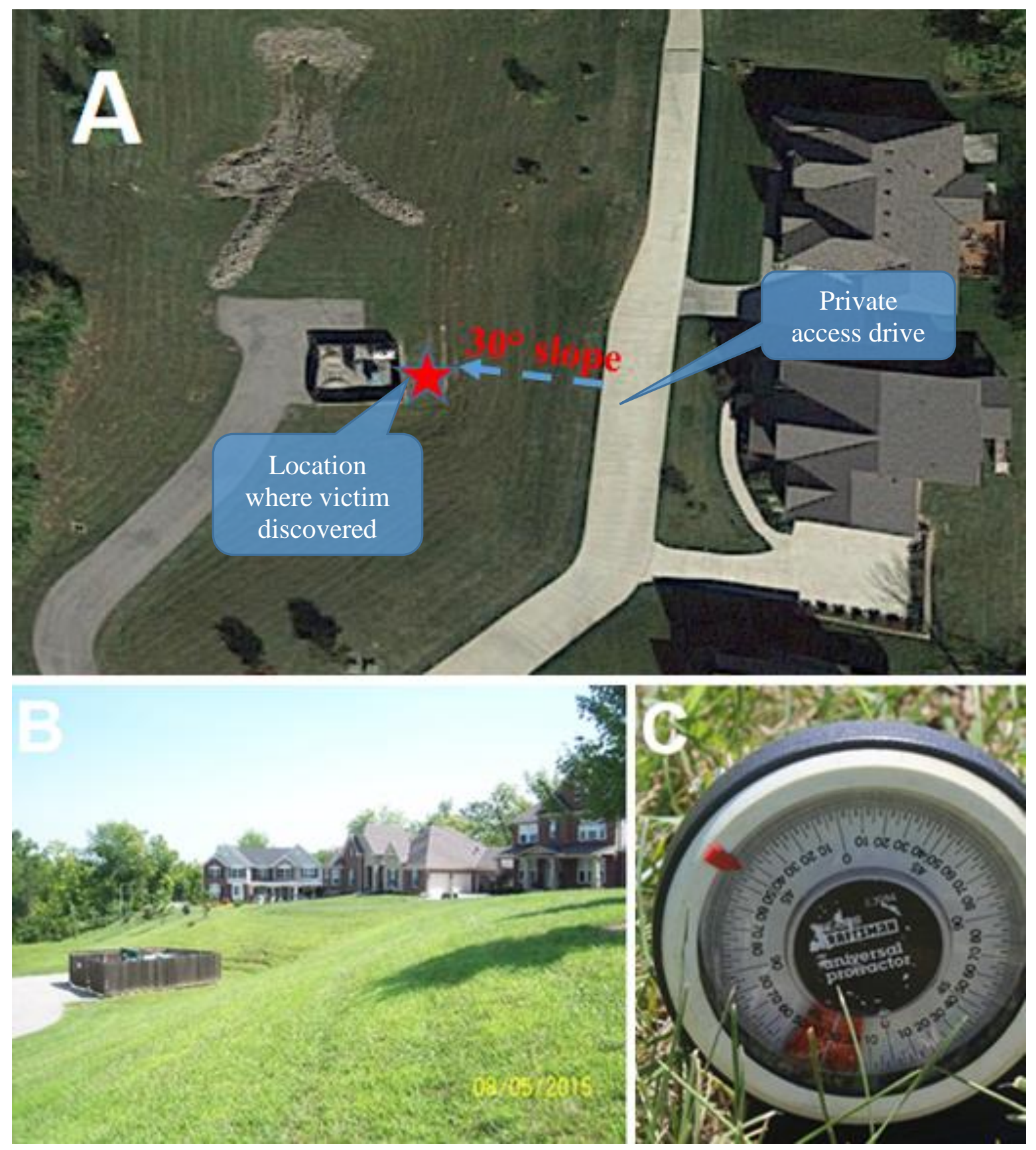

Figure 2. A) Aerial view with star denoting where the victim was discovered, B) side-view of the slope, C) slope reading of 30 degrees.

The incident occurred next to a private access drive in a residential subdivision. Four houses were positioned on the right side of the drive, with a steep embankment on the opposite side. The embankment where the roll-over occurred had a slope of 30 degrees. There was a fenced off area at the bottom of the embankment, where the victim was found. According to the employer, the victim had operated the same lawn mower in this location on several different occasions. 


\section{EQUIPMENT}

The equipment operated at the job site was a 2004 Scag brand Turf Tiger zero-turn mower, a model that weighs approximately 1,800 pounds (figure 3). The mower had a zero-turn radius and was capable of traveling at $12 \mathrm{mph}$. It was purchased without a roll over protection system, but it was equipped with a seat belt.

According to a representative for the employer, the user manual stated that the rollover bar was optional. The owner's manual clearly stated that while the rollover bar was optional, it should be used if the mower was to be operated on slopes or inclines to ensure operator safety. ${ }^{1}$

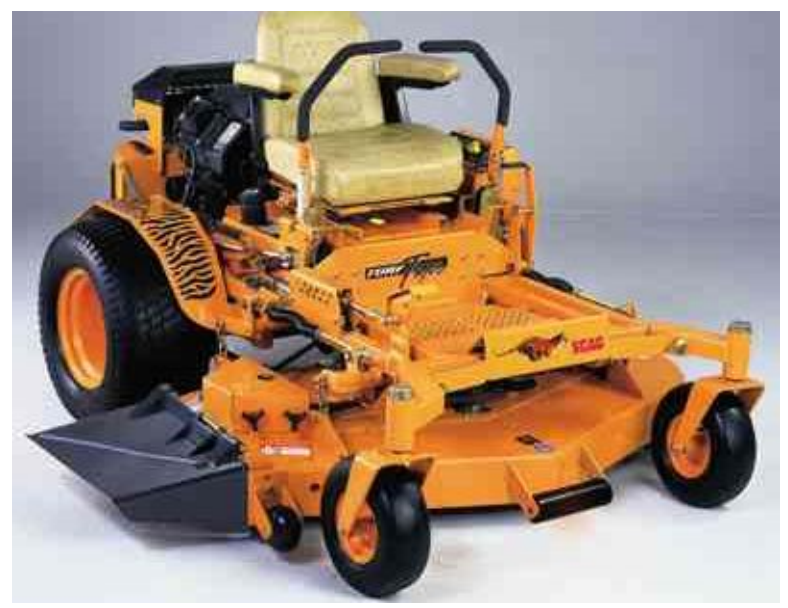

Figure 3. Stock photo of a Scag brand Turf Tiger zero-turn riding lawn mower without ROPS installed.

\section{WEATHER}

July 24, 2015 was a dry clear humid day. At the time of the incident, the temperature was approximately $77^{\circ} \mathrm{F}$ with a wind speed of $6.9 \mathrm{mph}$ coming from the south-southeast direction. Weather was not considered to be a factor in this fatality.

\section{INVESTIGATION}

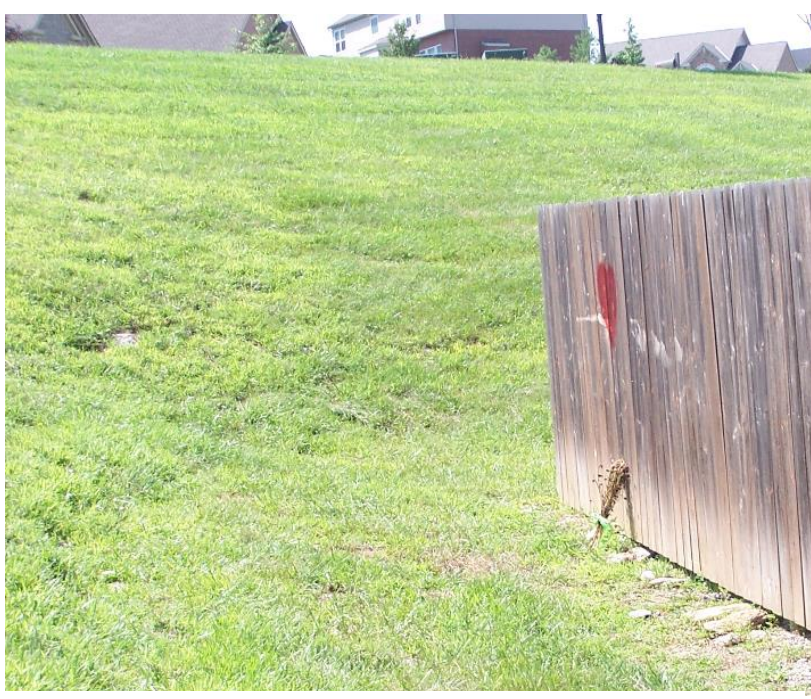

Figure 4. Flowers and a heart representing where the victim and overturned lawn mower were discovered.
On June 15, 2015, the Kentucky Labor Cabinet notified the Kentucky Fatality Assessment and Control Evaluation (FACE) Program of a fatality involving an over-turned lawn mower. An investigation was conducted.

A large, privately owned landscaping company was contracted to maintain the grounds of a gated residential subdivision. A crew of 4 landscapers arrived at the job site at 8:00 am. The victim was instructed to mow an area located near a private drive with four homes located on the right-hand side of the drive, and a steep embankment located on the left-hand side. Due to the approximate 30 degree angle of the slope, the victim was instructed to cut approximately 10 feet down the slope with the mower in this location, and the other lawn maintenance workers would return later to cut the rest of the embankment with string trimmers. The victim was to use a 2004 Scag brand Turf Tiger zero-turn mower to mow the area. 
According to the employer, the victim had mowed the grass in the area many times, using the same mowing equipment, before the incident occurred.

The supervisor and two other landscapers left the victim to his mowing while they operated weed trimmers in other areas. Upon returning to the victim's area at 10:28 am, they found the victim under the mower at the bottom of the hill against a wooden fence (figure 4). The supervisor, with the assistance of the other landscaper workers, rolled the mower off the victim, checked for vital signs and found none. The landscapers called 911 at 10:29 am and notified the company. It is unknown how long the victim had been under the mower before the supervisor and the other landscapers found him. The victim was pronounced dead at the scene by the coroner at 11:30 am.

\section{CAUSE OF DEATH}

The cause of death listed on the death certificate was asphyxia by chest compression caused by a lawn mower rollover.

\section{CONTRIBUTING FACTORS}

The investigation identified the following factors that may have contributed to the fatality:

- Operating a riding mower on a slope that exceeded manufacturer's specifications.

- The SCAG turf tiger riding mower was not equipped with a rollover protection structure.

- The employee was working alone.

\section{RECOMMENDATIONS AND DISCUSSIONS}

\section{Recommendation No.1: Never operate a lawn mower on a slope that exceeds the angle limits specified by the lawn mower manufacturer; use lawn maintenance equipment designated for steep slopes.}

The victim was mowing on a 30 degree incline, and the embankment was cut approximately 16 feet down from the top. The owner's manual states:
"Stay off slopes too steep for safe operation. To check a slope, attempt to back up the slope with the cutter deck down. If the machine cannot back up the slope without the wheels slipping, do not operate the machine on this slope. Under no circumstances should the machine be operated on slopes greater than 15 degrees",

Operating on a slope greater than the manufacturer's recommendation increases the likelihood of the mower overturning. If the slope is greater than 15 degrees, a push mower, string trimmer, or 
other specialized cutting equipment should be used. ${ }^{2}$ A push mower should be operated horizontally across the slope. If the slope falls within the manufacturer's recommended maximum slope for riding lawn mowers, a best practice is to mow up and down the slope rather than across the slope. ${ }^{3}$ Contact the manufacturer or refer to the user's manual to determine maximum slope safety specifications.

Recommendation No. 2: To prevent rollover injuries, riding lawn mowers should be equipped with roll-over protective structures (ROPS) and seat belts.

Equipping a mower with a ROPS and utilization of seat belts has shown to be effective in preventing serious injury and death due to overturns. This particular riding lawn mower model was available for purchase with a ROPS. It is strongly advised that riding lawn mowers be equipped with factory installed ROPS.

Recommendation No. 3: Employees should receive safety training on slope mowing with riding lawn mowers that includes slope calculation, manufacturer specifications, and terrain assessment.

The employer was unable to produce documentation showing that the victim received appropriate training on slope mowing with the Scag lawn mower. Employers should train employees on safe riding lawn mower operation (ANSI standards B71.1-2012:B71.4-2012: and ISO 21299:2009). The employees must demonstrate safe operations of the riding lawn mower.

Recommendation No.4: Employers should consider implementing a buddy system when working in hazardous areas such as steep slopes.

Allowing workers to perform job activities in pairs provides the opportunity for improved visual awareness of potentially hazardous environment.

\section{KEYWORDS}

Landscaping

Mowing

Steep slope

ROPS

\section{ADDITIONAL RESOURCES}

Dangers of Roll-Overs of Riding Mowers. OSHA.

[https://www.osha.gov/dsg/riding_mowers/]

Mowing and Trimming Safety. K-State Research and Extension 
[https://www.osha.gov/dte/grant_materials/fy09/sh-19503-09/mowingtrimming_safety_manual.pdf]

Golf Course Worker Dies After Being Pinned Under an Overturned Tee Box Mower. NIOSH FACE Program. [http://www.cdc.gov/niosh/face/stateface/mi/05mI060.html]

\section{REFERENCES}

${ }^{1}$ Owners manual. Scag Power Equipment. Web. [http://www.scag.com/OPManuals/STT/2005STTOPMAN/2005\%20STT\%20Operators\%20Man ual\%2003164\%20Rev\%201.pdf]

${ }^{2}$ Dangers of Roll-Overs of Riding Mowers. United States Department of Labor. [https://www.osha.gov/dsg/riding mowers/]

${ }^{3}$ Mowing and Trimming Safety. K-State Research and Extension. Web. [https://www.osha.gov/dte/grant_materials/fy09/sh-19503-09/mowingtrimming_safety_manual.pdf]

\section{PHOTO CREDIT}

Photo credit for figure 2A goes to Google Maps; 2C goes to Kentucky Occupational Safety \& Health (OSH) Program. All other photos taken by Kentucky FACE Program.

\section{ACKNOWLEDGEMENTS}

The Kentucky FACE program would like to thank KY OSH for their assistance with this report.

\section{PROGRAM FUNDING}

The Kentucky Fatality Assessment \& Control Evaluation Program (FACE) is funded by grant 2U60OH008483-11 from the Centers for Disease Control and Prevention and the National Institute for Occupational Safety and Health.

Please take the time to complete our brief survey regarding this report: (https://uky.az1.qualtrics.com/jfe/form/SV_3QvcTe61iufxYP3)

Electronic access to this full report can be found here: (http://www.mc.uky.edu/kiprc/programs/face/files/15KY041.pdf)

FACE on Social Media:

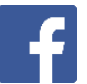

https://www.facebook.com/Kentucky-FACEProgram-

$\underline{134135740092906 / \text { ? view_public_for }=13413574009290}$
http://www.twitter.com/KYFACEProgra

$\underline{\mathbf{m}}$ 